\title{
ANALYSIS OF MARKETING AND LOGISTIC ASPECTS IN THEE-COMMERCE SECTOR - A CASE STUDY
}

\author{
Dominika Suliga \\ Czestochowa University of Technology \\ Faculty of Management
}

\begin{abstract}
This article presents marketing and logistic aspects on the example of e-commerce. Logistic and marketing issues integrate two concepts. On the one hand, logistics as a flow-oriented management concept, and on the other - marketing as a market-oriented concept of business management. The article aims to evaluate online sales activities executed by the retail network that operates in Poland. The results of the research are based on the data collected from the company and information obtained from the questionnaire. In the empirical part of the survey, the results of research conducted among consumers were presented. The survey was conducted in January 2018 in one of the grocery stores in Warsaw. Closed questions were used in the survey. The rapid development of e-commerce resulted in the flourishing of multi-channel distribution. Distribution logistics has a significant influence on customer satisfaction and cost optimization. In the case of the surveyed company, the combination of stationary and online commerce deserves particular attention. In practice, the integration of physical distribution with e-commerce brings many benefits.
\end{abstract}

Keywords: distribution logistics, e-commerce, logistics

DOI: $10.17512 /$ znpcz.2018.1.07

\section{Introduction}

Logistic and marketing aspects acquire special significance when the contemporary premises that determine the development and integration process of logistics and marketing, as well as the increase in their strategic importance in business management, are taken into account. The real phenomenon is the mutual interfusing of marketing and logistics (Łukasik, Bryl, Tatara 2016, p. 1725).

The main objective of marketing focuses on establishing a meaningful dialogue with the consumer, which results in offering the appropriate level and quality of service while minimizing operating costs. Thereby, it can be stated that the sphere of distribution is the point of contact between logistics and marketing. The flows of goods and information are the constituents of distribution channels. Customer service is recently perceived not only in the perspective of the foundation of building a competitive advantage but also as an element facilitating cooperation in the distribution channel.

The process of distribution is one of the most important elements of e-commerce. A properly carried out distribution has a significant impact on both customer satisfaction and cost reductions in the online store. 
E-commerce is one of the e-services provided in the information society. The Internet network is the fundamental e-commerce platform. It enables the companies to have direct access to its customers. Thanks to that each client can be treated individually. Customer service is tailored to the expectations, predispositions, and requirements of a given customer or client (Lis 2012, p. 1347).

The growing importance of the global Internet network has given the opportunity to develop the operations of market economy entities. The network created perfect conditions for running a business, not only because it was global, but also because access to it was possible 24 hours a day (Morejska, Kadłubek 2007, p. 54-55).

It is easy to acquire, collect and process customer data in a digital environment, which makes it easier to recognize customer needs and meet their expectations and desires (Jelonek 2014b, p. 20).

Logistics is usually associated with the flow of products and goods between the manufacturer, intermediary, and customer. The general definition of logistics is delivery of the product in accordance with the quality requirements of the customer, taking into account the appropriate amount. The goods should be delivered to the customer in the right place and at a certain time after all costs have been taken into account (Lis, Bajdor, Tomski 2014, p. 55).

The most important logistic elements of customer service include delivery time, reliability, communication, and convenience (supplier's flexibility) (Kozerska 2010, p. 1553).

Distribution process can be associated with a number of activities related to overcoming spatial and temporal differences between production and consumption (Kadłubek 2012, p. 482).

The importance of distribution processes in the effective functioning of a logistic system results from (Nowicka-Skowron 2001, p. 38):

- the necessity to reduce the total logistic costs in the distribution channel, which in turn stems from the increasing competition on the market and declining profitability of sales;

- the possibility of achieving competitive advantage by increasing the level of delivery service, and thus increasing the level of customer service.

The efficiency of work in the distribution channel can be seen as the ratio of realization effects (timeliness, quality or reliability of deliveries) to expenses incurred (financial, operational, material and human) (Bajdor 2017, p. 43-52).

Distribution is a marketing tool that interacts with the market. The distribution is based on overcoming temporary, quantitative, spatial or assortment barriers. Its purpose is to organize the flow of goods to the final recipient managing the company's distribution system (Kabus, Nowakowska-Grunt 2017, p. 277).

From a macroeconomic point of view, distribution implies a process and structure of relocation of goods from manufacturers to final recipients. However, from the microeconomic point of view, it is often identified with the process of selling and delivering products of a given company to its final buyers (Dohn, Matusek, Odlanicka-Poczobutt 2012, p. 99). 
The field of logistic distribution processes is extensive. The areas that can be distinguished here include raw materials ordering, stock forming, transportation and finished products packets (Biniasz 2015, p. 404).

The distribution channel is a way of reaching the final recipient. In the distribution channel, both its length and width can be singled out. The length of the distribution channel on the Internet is the primary length - the manufacturer himself delivers the goods to the customer or uses services of courier companies. The width of the distribution channel on the Internet is unlimited. It is conditioned by the fact that the Internet has no place and time restrictions. In this case, the delivery of goods takes place directly - using the Internet connection, or through the agency of deliverers (e.g., couriers) (Dejnaka 2002, p. 83-84).

Companies should orchestrate and develop a multi-channel offer while dealing with customers. The emergence of e-commerce revolutionizes work organization in enterprises. The Internet nowadays is used by companies as a communication tool to interact with customers (Jelonek 2014a, p. 322).

In addition to traditional distribution channels, there are also electronic distribution channels.

\section{Electronic distribution channels}

In the case of an electronic distribution channel, the flows are performed in two aspects: electronic and physical. The division of streams between these two groups is conditioned by the type of participants in the channel, products sold, technological capacities and available resources (Pluta-Zaręba, Rutkowski 2005, p. 218).

In electronic and traditional distribution channels, the flow paths of streams are diversified and performed by distinct and qualified economic entities (Kotler 1994, p. 482).

The paramount functions of distribution include overcoming time, space and quantity barriers. Therefore, it is necessary to make continuous decisions and estimate the number of tasks performed by a given company (Urbańska 2008, p. 13).

In economy, the process of distribution exercises both coordinative and organizational functions (Korczak 2013, p. 30).

Multi-channel distribution, or in other words the "bricks and clicks" model, refers to the activity of a trade organization that combines the electronic channel with the traditional channel. It is a model of managing a commercial business, which integrates two activities: virtual and traditional. Being complementary to one another, the channels strengthen their actions by utilizing the advantages of each of them. The expansion of distribution with an electronic channel results in a competitive advantage in combination with retailers who operate only in traditional trade (Goska 2014, p. 27-28). 


\section{Analysis of marketing and logistic aspects in the e-commerce sector - a case study}

In the surveyed company, the guarantee of a high level of customer service is associated with the appropriately performed delivery of goods, carried out by the use of various forms of delivery. These include the delivery of goods by a courier company, inland transport, and an individual pick-up at a stationary store.

The first step of placing a collect-from-store order is to log into the Internet account, and then to select products. Afterwards, the client is asked to enter the postcode, pick a convenient date of the pick-up of purchases at the stationary store, and finally click the collect from store button. The customer should receive a confirmation of the order to his e-mail address. To pick-up the ordered goods, the customer is obliged to provide the order number. If the purchaser does not show up to collect the ordered goods, the batch is invalidated. The order must be placed at least two hours before the collection of the products.

The date of delivery is chosen immediately after online shopping is finished. The enterprise can provide the buyer with the ordered goods on a daily basis from 10 a.m. to 10 pp.m. The driver is obliged to call the customer before delivering the goods. In the case of an ineffective delivery because of customer's fault, the client is charged with the costs of the unfinished delivery. The products are transported in cars equipped with refrigerators or iceboxes, which are adjusted to fresh and frozen goods and products.

The examined enterprise facilitates the complaint or refund procedure. The complaint can be resolved by the courier straight away. The purchaser has the right to withdraw from an agreement within ten days from the delivery date without stating the cause. The only exception is fresh products. The customer can withdraw from the agreement either by drafting a document or by sending a questionnaire via the website. The surveyed enterprise accepting the complaint is obliged to return the money for the products along with the shipping costs.

The residents of Warsaw and its agglomerations may use the product delivery option with the so-called coolomat ${ }^{1}$. When ordering goods, the customer can choose the form of delivery. The next step is choosing the place and indicating the most suitable delivery time that suits the customer. Once the order is confirmed, the buyer receives an SMS with a place and exact date the delivery can be collected from a coolomat. In this case, the supplier stows the product in a given coolomat within four hours from the moment the order has been placed. Purchasers can pay only by using online transfers or credit cards.

The ordering process itself is carried out quickly and optimally, thanks to which customers will not have the slightest problem to make purchases again in the future.

\footnotetext{
${ }^{1}$ A machine adjusted for storing and collecting groceries ordered from online stores.
} 


\section{Research aim and data analysis}

The aim of the survey was to present the results of the research that revolved around the evaluation of the operation of e-commerce performed by a retail network.

The analysis of the surveyed enterprise was formulated on the basis of the data collected from that enterprise, and the information obtained from the survey that was filled by the customers of the company in Warsaw. The questionnaire provided the data for enterprise evaluation, influenced by deliveries of goods to online clients. All questions in the survey were closed questions.

The first part of the survey is an instruction that shows the way the survey is supposed to be filled. The second part pertains to questions based on distribution logistics in the studied enterprise. The last part of the survey concerns customer's data.

The questionnaire allowed to present the situation seen through the eyes of the customer. At the same time, it brought out a number of problems that exist in this institution.

The survey was completed by one hundred people, who did shopping in one of the Warsaw stores. Moving on to the analysis of the questionnaire, we would like to specify that in the group of customers, the largest number of e-buyers is in the age group of 31-35 (41\%), and 36-40 (36\%). They are people who live a rapid, professionally active life, for whom doing online shopping is not to be overestimated. $45 \%$ of the online customers have higher education, $36 \%$ secondary education, $14 \%$ vocational education, and $5 \%$ primary (elementary) education. $95 \%$ of the respondents stated that they are the residents of Warsaw.

The first question regarding the analysis was aimed at selecting people who make purchases via the Internet. The research indicates that $65 \%$ of the respondents (65 people) make purchases via the Internet. Another question was addressed to people who do not shop online at all. Figure 1 below presents the percentage of the responses.

35 customers do not shop online at all. The main reason why $71 \%$ of the customers do not engage in e-commerce is that the entire process is too complicated and problematic (Figure 1). 11\% of the customers would like to see the product before buying it, and the inability to do so discourages them effectively from online shopping. $12 \%$ of the respondents fear that the quality of the delivered product may turn out to be inadequate and completely different. Another $6 \%$ of the respondents believed that the delivery cost of the ordered goods was too high. To sum up, it can be stated that the surveyed company should redevelop the webpage in a way that facilitates online shopping, making it more clear and understandable. 


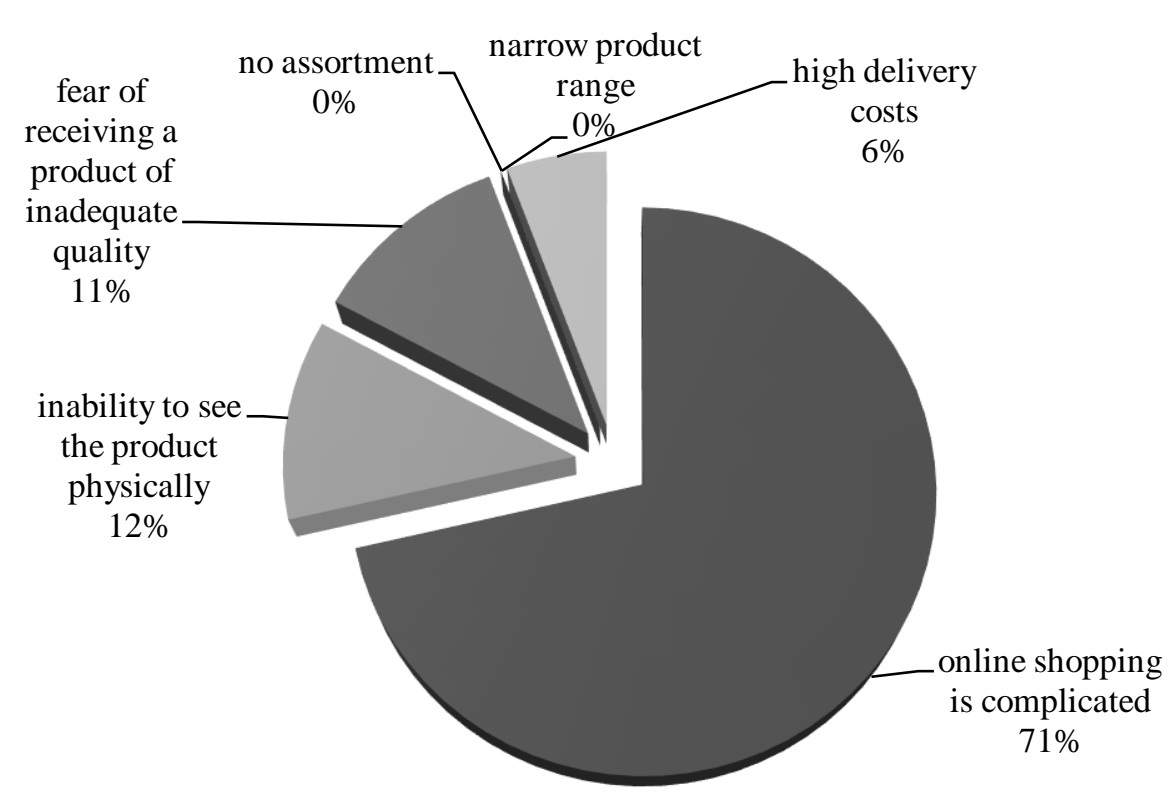

Figure 1. What's the reason for not purchasing online in the enterprise $X$ ?

Source: Own study based on the conducted survey

The next batch of questions was directed at the 65 clients who use enterprise's online store for online shopping. The results are as follows: $25 \%$ of the interviewees stated that they had been customers of this enterprise for 3 years. Another $15 \%$ of the customers said that they had been customers of the store for about two years. A large majority $-46 \%$ of the customers have been its customers for a period shorter than a year, and the remaining $14 \%$ for more than three years. It can be concluded that the company in order to win over more clients should advertise more, particularly on the Internet, radio, and television.

As it can be seen from Figure 2 below, free delivery (38\%) and loyalty programs $(32 \%)$ are the most important aspects that determine people's willingness to do the shopping via online stores. The price of products is also important and is often taken into consideration by potential customers. Subsequently, the list continues with promotions (8\%), first purchase discounts (3\%), delivery price (5\%) and website transparency $(2 \%)$ as consecutive aspects that determine people's choice of online stores. 


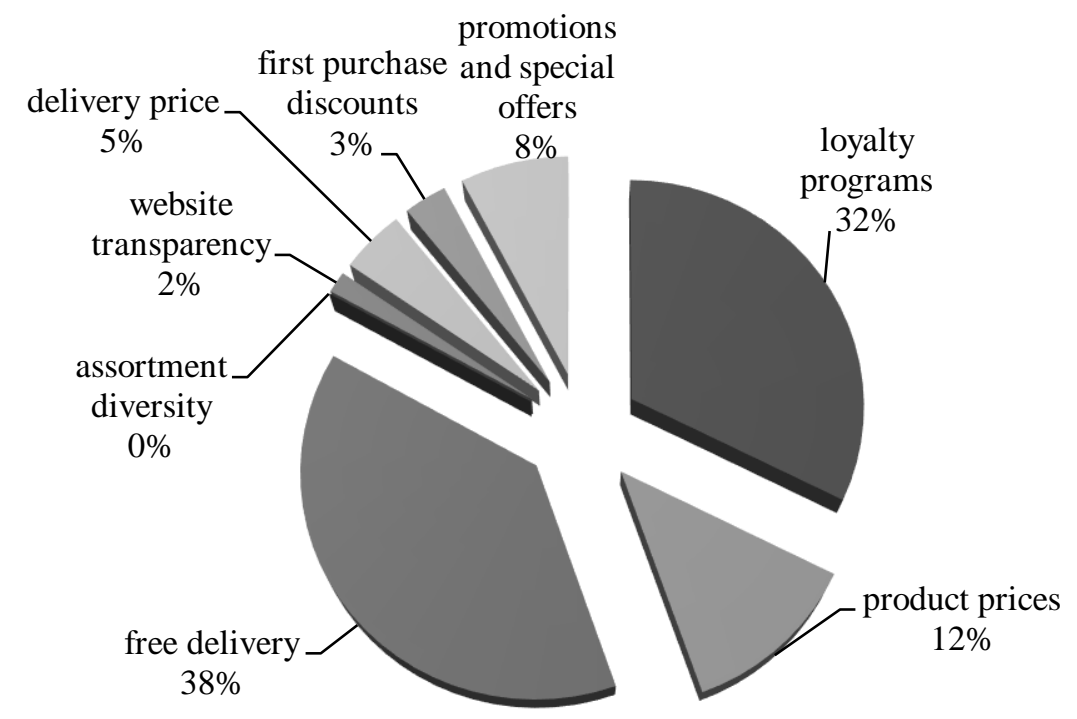

Figure 2. Which of the following aspects determine the choice of online stores in the food industry?

Source: Own study based on the conducted survey

The next question was as follows: How often do you shop in the online store? After a thorough analysis of the collected data, it can be pointed out that $54 \%$ of the respondents use the Internet for shopping every week, 23\% twice a week, $18 \%$ once in a month, and 5\% use online stores for shopping every day.

Another question that was asked concerned the amount of money that people spend during one shopping session in the studied store. The data were presented graphically below.

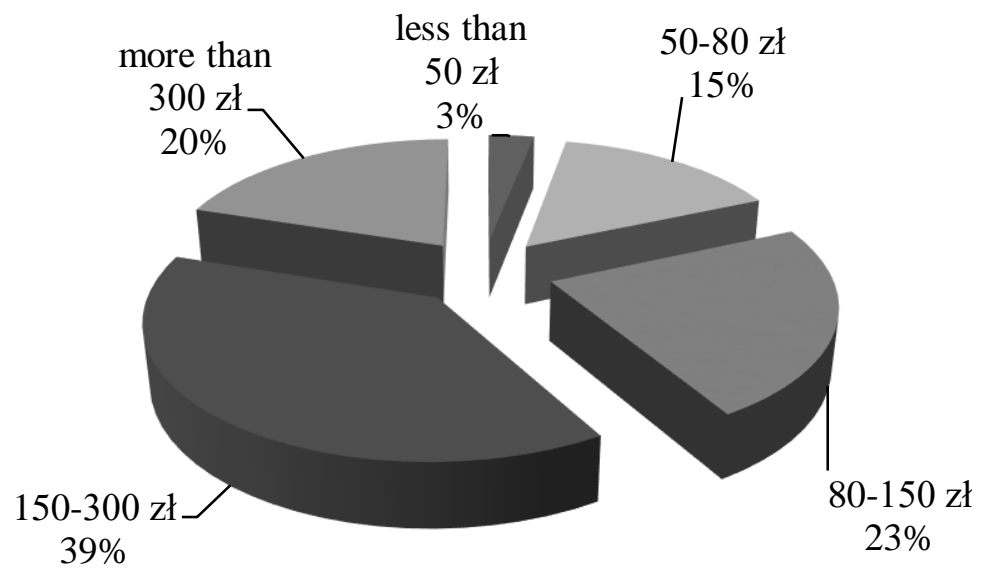

Figure 3. How much money do you spend in one shopping session in the online store of enterprise $X$ ?

Source: Own study based on the conducted survey 
$39 \%$ of the survey respondents confirmed that in one shopping session they spend from 150 to $300 \mathrm{zl}$ (Figure 3). The rest of the data looks as follows: $23 \%$ spend $80-150 \mathrm{zl}, 20 \%$ more than $300 \mathrm{zl}, 15 \%$ spend $50-80 \mathrm{zt}$, and $3 \%$ less than $50 \mathrm{zł}$.

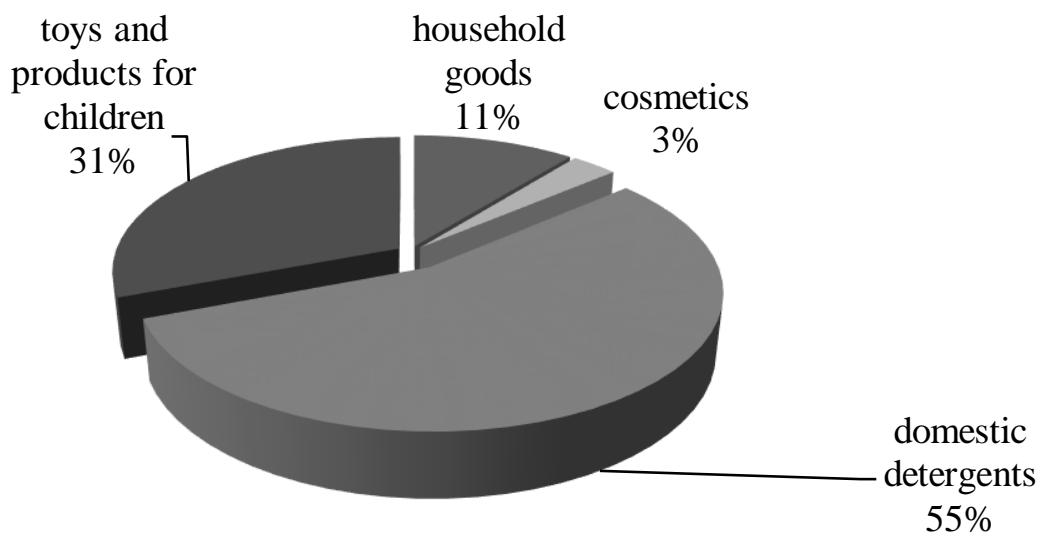

Figure 4. Which of the following items do you usually buy from the online store of enterprise $X$ ? (except groceries)

Source: Own study based on the conducted research

The next question was about the most frequently purchased items in the surveyed online store (Figure 4). Groceries were not taken into consideration here. The results indicate that the interviewees buy domestic detergents $(55 \%)$ and toys or products for children (31\%) most often. Household goods (11\%) and cosmetics (3\%) occupy next positions.

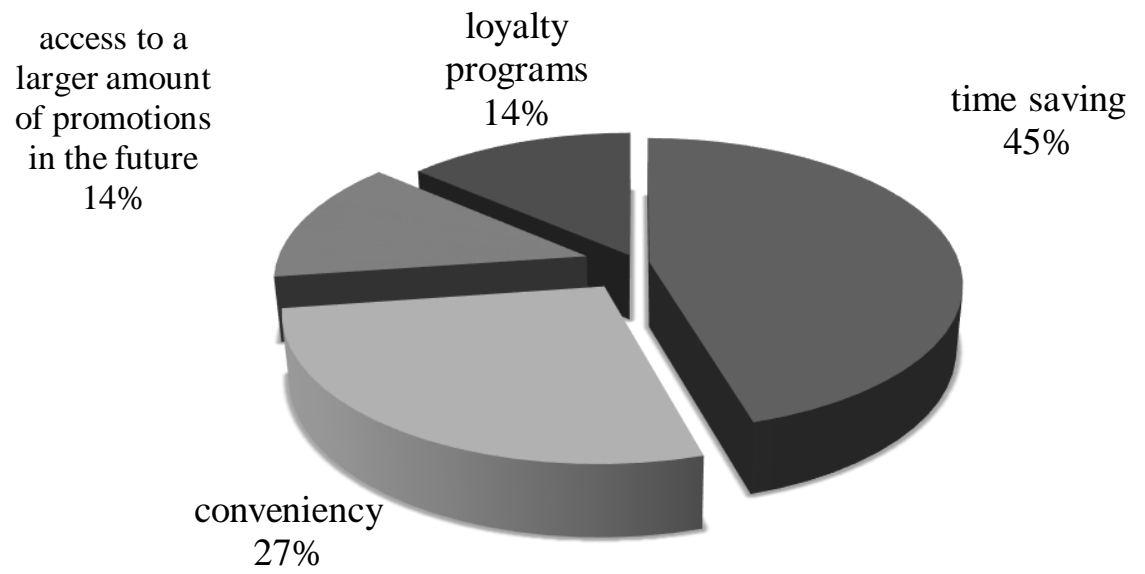

Figure 5. What affects the desire to shop online in the surveyed enterprise?

Source: Own study based on the conducted survey 
The data presented on the pie chart above indicate that time-saving (45\%) and convenience $(27 \%)$ are the most important factors that affect people's willingness to shop online (Figure 5). Loyalty programs (14\%) and promotions (14\%) are also considered by people but to a lesser degree.

Further, in the questionnaire the customers were asked to complete a table. A number of factors that may encourage people to do shopping online were listed, and the respondents had to estimate which ones are the most important. The scale consisted of numbers from 1 to 5 , with 1 being the least important factor, and 5 being the most important.

Table 1. Factors encouraging people to do shopping online in the analyzed enterprise

\begin{tabular}{|c|c|c|c|c|c|}
\hline Factors & 1 & 2 & 3 & 4 & 5 \\
\hline $\begin{array}{c}\text { Special product sales } \\
\text { and promotions }\end{array}$ & & & & 5 & 60 \\
\hline $\begin{array}{c}\text { Discounts on the } \\
\text { entire order }\end{array}$ & & & & & 65 \\
\hline Free delivery & & & 5 & 4 & 56 \\
\hline Loyalty program & & & & & 65 \\
\hline Free of charge goods & & & & & 36 \\
\hline Fast delivery time & & & & & \\
\hline
\end{tabular}

Source: Own study based on the conducted survey

The results of the questionnaire indicate that most customers pay special attention to discounts on the entire order, as well as free and fast deliveries. 60 people stated that promotions and sales on individual products are most important for them, whereas 5 pointed out that it is important for them. Discounts, free and fast deliveries are most important for all surveyed customers that visit online stores. The loyalty program is the most important for 3 people, whereas 60 people think that it is important and 2 people consider it to be moderately important. In the case of free of charge goods, 56 respondents stated that they are most important for them, 4 said they are important, and 5 claimed them to be moderately important. Another question referred to purchases where mobile phones are used. The study shows that $20 \%$ of the interviewees do the shopping with applications installed on their smartphones. A vast majority of the respondents (80\%) do not use mobile applications for shopping at all. It may be conditioned by an unintelligible website or maladjusted forms. 
Wanting to guarantee its customers a high level of service, the studied enterprise offers its purchasers various forms of delivery. The delivery of shopping to customers from outside of Warsaw is carried out by a courier company. The company in Warsaw offers the possibility to collect goods from the so-called coolomat. Despite such a wide range of options of product delivery, $65 \%$ of clients choose their products to be delivered straight to their door, whereas the remaining $35 \%$ prefer a personal pick-up. Personal pick-up is a very comfortable and convenient way of delivery because there is no need to wait for a courier at home. The customers in Warsaw can pick-up the ordered goods at the Customer Service Point.

Another question was related to the safety of transported goods. All the respondents stated that they put great trust in the analyzed company considering the conditions in which their purchases are transported, as they believe that they are transported safely and securely.

In the survey, the respondents were also asked the following question about package delivery: Has it ever happened to you that the ordered package was not delivered? Analyzing the data, we found out that only two customers did not receive their ordered packages.

Customer satisfaction in connection with the timeliness of deliveries was also examined and researched in the survey. 35\% of the respondents expressed their dissatisfaction with the time of delivery. In the surveyed enterprise the employees have to remember the fact that both the timeliness and flexibility of delivery are considered to be particularly significant factors in this business. The company must synchronize the time and methods of delivery of products to meet specific expectations of its customers. The timeliness and completeness of deliveries are constituents that ensure delivery reliability in the studied company.

Another question concerned the quantity and frequency of orders during pre-holiday breaks. The respondents were asked, whether, for example, the pre-Christmas period influences the amount and incidence of orders performed by them. The research indicates that $75 \%$ of the customers do shopping online in these periods, and it can be assumed that this tendency will continue, or will even increase in the future because people choose online shopping more and more often. It can be concluded that in periods of increased and intensified traffic in the industry, the company should particularly focus on logistic challenges. The information obtained from the surveyed company state that the average number of orders on a weekday is around 22 orders, whereas during the pre-holiday period that amount increases to 60 deliveries daily. In order to increase the efficiency and customer satisfaction, the company should consider the use of services of a courier company.

Finally, the respondents were asked if they ever returned goods or products purchased online. The data inform that $34 \%$ of clients returned the order. There can be many reasons for such a situation, one of them could be a consumer complaint. In this case, customers can place a complaint on a given commodity, once the ordered product meet their expectations. The purchaser can either return it immediately or wait for the supplier to arrive. The customer fills out a return form and settles the payment. 


\section{Conclusions}

Logistic and marketing aspects seem to play an especially important role in the success of the enterprise. The process of distribution is one of the most crucial elements of e-commerce. Properly conducted, distribution logistics has an impact on cost reduction and customer satisfaction.

The article aimed to evaluate online sales activities executed by a retail network that operates in Poland. The analysis conducted in the article was based on the research and data taken from an enterprise located in Warsaw. The development of e-commerce resulted in the flourishing of multi-channel distribution. In the case of the surveyed company, the combination of stationary and online commerce deserves particular attention.

The relation between marketing and logistics makes use of an idea that the starting point for the development of a logistic strategy should be posed by the concepts of marketing strategy that concern the product, price and promotional activities in relation to the distribution channels used. Logistic distribution that is carried out properly has a large impact on both customer satisfaction and cost optimization.

Investments related to e-commerce caused an increased interest in shopping. The more convenient shopping process in the online store is largely different from that in a stationary store. The following aspects should be distinguished when comparing traditional commerce with e-commerce:

- in e-commerce there is no direct contact between the purchaser and vendor, the client is unable to touch or smell the product. As for the advantages, one can favor the comparison of prices and items, as well as the possibility of home deliveries.

- in a stationary store, clients may not only count on competent salespeople but also get familiar with the assortment of products both visually and tactually.

The possibility to pick-up the ordered goods turned out to be a great convenience for the customers of the surveyed company. The collection of goods at a given pick-up point ensures comfort, saves time and proves flexibility. The customers save time that would be necessary for shopping at a stationary store. It is very often an alternative to the delivery of goods straight to the customer's door. The person that places an order wishes for the order to be delivered at the appropriate time and directly to the indicated place. The analyzed company perceives e-commerce as a way of gaining the competitive advantage.

35 out of 100 the respondents do not shop online. The author notes the need to study the reasons that discourage people from e-shopping, and potential factors that may affect the change of that decision. The research would be an answer to a key question regarding the most effective and successful methods of gaining new clients in the electronic trade sector. 


\section{Literature}

1. Bajdor P. (2017), Efektywność pracy w kanale dystrybucji, [in:] Nowakowska-Grunt J., Starostka-Patyk M. (red.), Logistyka dystrybucji, Wydawnictwo Komunikacji i Łączności WKŁ, Warszawa, p. 43-52.

2. Biniasz D. (2015), Logistyka dystrybucji u dostawcy przemystowego - studium przypadku, "Logistyka", nr 3, p. 404-412.

3. Dejnaka A. (2002), CRM. Zarzadzanie kontaktami z klientami, Helion, Gliwice.

4. Dohn K., Matusek M., Odlanicka-Poczobutt M. (2012), Ocena efektywności kanałów dystrybucji w wybranym przedsiębiorstwie produkcyjnym - część I, "Logistyka", $\mathrm{nr} 4$, p. $99-106$.

5. Goska S. (2014), Nowoczesne kanały dystrybucji produktów bankowych - porównanie ofert wybranych banków, "Finanse i Prawo Finansowe", nr 2, p. 23-37.

6. Jelonek D. (2014a), Ocena internetowych kanałów komunikacji z klientem $w$ procesie wspóttworzenia innowacji, "Informatyka Ekonomiczna", $\mathrm{nr}$ 1(31), p. 318-329. DOI: 10.15611/ie.2014.1.24

7. Jelonek D. (2014b), Zarzadzanie relacjami z klientami $w$ wirtualnym otoczeniu organizacji, "Studia i Prace Kolegium Zarządzania i Finansów", nr 136, p. 19-31.

8. Kabus J., Nowakowska-Grunt J. (2017), Managing the Company's Distribution System, "World Scientific News", No. 78, p. 277-283.

9. Kadłubek M. (2012), Zarzadzanie procesami dystrybucji w przedsiębiorstwie, "Logistyka", nr 5, p. 482-489.

10. Korczak J. (2013), Inżynieria procesów logistycznych, Wydawnictwo Uczelniane Wyższej Szkoły Gospodarki w Bydgoszczy, Bydgoszcz.

11. Kotler P. (1994), Marketing. Analiza, planowanie, wdrażanie i kontrola, Wydawnictwo Feberg, Warszawa.

12. Kozerska M. (2010), Logistyczna obstuga klienta jako imperatyw działania w tańcuchu dostaw (Część II), "Logistyka”, nr 6, p. 1553-1564.

13. Lis T. (2012), Handel elektroniczny w społeczeństwie informacyjnym - Polska na tle innych krajów Unii Europejskiej, "Logistyka", nr 3, p. 1345-1353.

14. Lis T., Tomski P., Bajdor P. (2014), The Optimization of Information Logistics as the Determinant of Competitive Advantage of an Enterprise in Turbulent Environment, "Logistyka", nr 5, p. 55-58.

15. Łukasik Z., Bril J., Tatara K. (2016), Zarzadzanie marketingowo-logistyczne, "Autobusy. Technika, Eksploatacja, Systemy Transportowe", nr 6, p. 1725-1730.

16. Morejska K., Kadłubek M. (2007), Narzędzia promocji i dystrybucji internetowej, [in:] Skibińska W., Skowron-Grabowska B. (red.), Determinanty zarządzania i rozwoju przedsiębiorstw w Unii Europejskiej, Wydawnictwo Politechniki Częstochowskiej, Częstochowa, p. 54-55.

17. Nowicka-Skowron M. (2001), Efektywność systemów logistycznych, PWE, Warszawa.

18. Piasecka-Głuszak A. (2004), Logistyka w wydawnictwie, Biblioteka Analiz, Warszawa.

19. Pluta-Zaręba A., Rutkowski K. (2005), Logistyka dystrybucji w erze Internetu, [in:] Rutkowski K. (red.), Logistyka dystrybucji. Specyfika. Tendencje rozwojowe, Oficyna Wydawnicza SGH, Warszawa, p. 211-242.

20. Skowronek C. (2003), Logistyka w przedsiębiorstwie, PWE, Warszawa.

21. Urbańska J. (2008), Klient a dystrybucja - relacje i implikacje, Wydawnictwo Politechniki Częstochowskiej, Częstochowa. 


\section{PRZEDSTAWIENIE NA WYBRANYM PRZYKŁADZIE ASPEKTÓW MARKETINGOWO-LOGISTYCZNYCH W SEKTORZE HANDLU ELEKTRONICZNEGO}

Streszczenie: Niniejszy artykuł przedstawia aspekty marketingowo-logistyczne na przykładzie handlu elektronicznego. Zagadnienia logistyczno-marketingowe stanową swego rodzaju integracje dwóch koncepcji. Pierwszą z nich jest logistyka, zorientowana na przepływy, natomiast drugą koncepcją jest marketing, postrzegany jako zorientowana rynkowo koncepcja zarządzania organizacją. Celem artykułu jest ocena działań sprzedażowych on-line realizowanych przez sieć detaliczną działającą w Polsce. W części empirycznej przedstawiono wyniki badań przeprowadzonych wśród konsumentów oraz danych zebranych $\mathrm{z}$ analizowanego przedsiębiorstwa. Ankieta została przeprowadzona w styczniu 2018 roku, w jednym ze sklepów spożywczych w Warszawie. W ankiecie użyto pytań zamkniętych. Szybki rozwój e-commerce zaowocował rozkwitem dystrybucji wielokanałowej. Logistyka dystrybucji ma znaczący wpływ na zadowolenie klientów i optymalizację kosztów. W przypadku badanej firmy na szczególną uwagę zasługuje połączenie handlu stacjonarnego i internetowego. W praktyce integracja fizycznej dystrybucji z e-commerce zapewnia wiele korzyści.

Słowa kluczowe: logistyka dystrybucji, handel elektroniczny, logistyka 